\title{
Sequential Voltammetric Determination of Chromium, Thallium, Cadmium, Lead, Copper and Antimony in Saline Hemodialysis Concentrates using Electrolyte pH Gradient
}

\author{
Paulo C. Nascimento, * Alexandre B. Schneider, Denise Bohrer, \\ Leandro M. de Carvalho and Cristiane L. Jost \\ Departamento de Química, Universidade Federal de Santa Maria, \\ CP 5051, 97105-970 Santa Maria-RS, Brazil
}

\begin{abstract}
A determinação sequencial de cromo, tálio, cádmio, chumbo, cobre e antimônio em concentrados polieletrolíticos para hemodiálise (DCs) é apresentada. Cromo foi determinado usando voltametria adsortiva de redissolução catódica e tálio, cádmio, chumbo, cobre e antimônio por meio de voltametria de redissolução anódica. O novo método desenvolvido para testar estas amostras se baseia no efeito do gradiente de $\mathrm{pH}$ do eletrólito na resposta voltamétrica. Os limites de detecção variaram de $0,03 \mu \mathrm{g} \mathrm{L}^{-1}$ para cádmio a $0,27 \mu \mathrm{g} \mathrm{L}^{-1}$ para cobre. Recuperações das amostras variaram de 92,0 a 117,5\%. Este método foi aplicado para a análise de DCs comerciais, nos quais as concentrações encontradas dos analitos variaram de $0,16 \mu \mathrm{g} \mathrm{L}^{-1}$ para antimônio até $140,00 \mu \mathrm{g} \mathrm{L}^{-1}$ para cobre. Interferências e método de referência são discutidos.
\end{abstract}

The sequential voltammetric determination of chromium, thallium, cadmium, lead, copper and antimony in dialysate concentrates (DCs), is presented herein. Chromium was quantified by adsorptive cathodic stripping voltammetry and thallium, cadmium, lead, copper and antimony were assayed by anodic stripping voltammetry. The novel method developed to test these samples exploits the effect of electrolyte $\mathrm{pH}$ gradient on voltammetric response. The limits of detection (LOD) ranged from $0.03 \mu \mathrm{g} \mathrm{L} \mathrm{L}^{-1}$ for cadmium to $0.27 \mu \mathrm{g} \mathrm{L}^{-1}$ for copper. Recoveries from spiked samples were $92.0-117.5 \%$. This method was applied to the analysis of commercial DCs, where the investigated metals were found in some samples at concentrations between $0.16 \mu \mathrm{g} \mathrm{L}^{-1}$ for antimony and $140.00 \mu \mathrm{g} \mathrm{L}^{-1}$ for copper. Interferences and the reference method are discussed.

Keywords: sequential voltammetry, dialysate concentrates, trace metals, contamination

\section{Introduction}

Hemodialysis has been successfully used since the mid 1900s (W. J. Kolff used the first dialysis machine in $1943)^{1}$ to increase the survival time of dialysis patients. The fluid used during dialysis therapy (dialysate) is prepared just before each hemodialysis session by mixing hemodialysis water (HW) with commercially available saline hemodialysis concentrates (DCs). HW and DCs are produced according to strict quality control regulations to avoid chemical and microbiological contamination. The maximum permissible contaminant levels in HW are set by national and international standards, such as the Association for the Advancement of Medical Instrumentation (AAMI) recommended practices for

*e-mail: pcn1954@gmail.com dialysis water treatment systems (ANSI/AAMI RD 52 and 62). Nowadays, the quality control and production of HW fulfill the international standards, at least in developed countries. However, there are no regulatory rules for trace chemical contaminants in DCs, likely due to the scarce number of accessible methodologies that are directly applicable to such samples. Indeed, DCs exhibit a very high ionic strength ( $\left.c a . \mu=4.1 \mathrm{~mol} \mathrm{~L}^{-1}\right)$, mainly due to chloride and sodium concentrations, with minor contributions from calcium, magnesium, potassium and acetates. In previous studies of the salts used to make up DCs, we found the presence of natural contamination from heavy metals ${ }^{2}$ as well as the contamination of some commercial DCs by cadmium, thallium, lead ${ }^{3}$ and copper. ${ }^{4}$ This should be not surprising when one takes into account that salts, such as $\mathrm{KCl}$ and $\mathrm{NaCl}$, which are labeled by Merck as "Suprapur grade", should contain no more than $0.1 \mathrm{mg} \mathrm{L}^{-1}$ of cadmium, 
lead and thallium. For Merck's AR grade, the tolerable limit is even higher (ca. 0.001\%). Although the main portion of trace metal-related problems in dialysis patients is attributed to the toxic effects of aluminum, ${ }^{5-8}$ a number of other elements can also be dangerous.

In the present work, a novel scheme is proposed for the sequential and simultaneous determination of chromium, thallium, cadmium, lead, copper and antimony in DCs. This method exploits the effect of the electrolyte $\mathrm{pH}$ gradient on the voltammetric response. This approach, based on stripping voltammetry with a hanging mercury drop electrode (HMDE), has very low detection limits and excellent selectivity against other co-existing ionic species in undiluted samples. The latter aspect is very important for DCs, considering the challenge of detecting metallic traces in solutions with very high salt concentrations.

It is important to emphasize that electrothermal atomic absorption spectroscopy (ETAAS), the most popular analytical technique for trace metal analysis, fails to directly assay trace metals in DCs. This is because either metallic contaminants are close to the limits of determination of linesource electrothermal atomic absorption spectrometry (ETAAS) or the precision is not sufficient in these media. ${ }^{9-11}$ Therefore, to overcome this difficulty, large sample dilutions or time consuming clean-up/preconcentration procedures using conventional ion exchangers and sorbents need to be considered. Conversely, electrochemical methods are adequate for saline matrices and voltammetric techniques can be a desirable analytical choice, considering their relatively low cost, simplicity, good sensitivity and selectivity, in addition to the possibility of simultaneous and sequential determinations. Among the voltammetric techniques, stripping analysis was used herein owing to its high sensitivity. Indeed, the in situ preconcentration step increases the sensitivity, yielding detection limit improvements of up to $10^{5}$ times compared with direct voltammetric methods. ${ }^{12}$

\section{Experimental}

\section{Apparatus}

Alternating current (AC) and differential pulse (DP) voltammograms were recorded using a 693 VA Processor and a 694 VA Stand (Metrohm AG, Herisau, Switzerland), including a regular mercury multi-mode electrode (MME) from Metrohm. A platinum wire was used as the auxiliary electrode, and all the potentials were quoted against a $\mathrm{Ag} / \mathrm{AgCl} / \mathrm{KCl} 3 \mathrm{~mol} \mathrm{~L}^{-1}$ reference electrode. Voltammetric measurements were made in a conventional voltammetric cell $(20 \mathrm{~mL})$. The standard addition method was used to evaluate analyte concentrations through peak current measurements. Adjustments in $\mathrm{pH}$ for the $\mathrm{pH}$ gradient were carried out by inserting a combined glass electrode (Metrohm) in the voltammetric cell. For pH measurements, a Digimed DM 20 (Digimed, São Paulo, Brazil) pHmeter was used.

Solutions were thermostated at $20 \pm 0.5^{\circ} \mathrm{C}$ and deaerated with water-saturated pure nitrogen for $300 \mathrm{~s}$ prior to analysis. Shortly before use, the voltammetric cell was rinsed in a $10 \% \mathrm{HNO}_{3}$ in ethanol (v/v) mixture and washed with demineralized water using a Milli-Q system (Millipore, Bedford, USA).

\section{Reagents and solutions}

All acids, ammonium hydroxide, sodium nitrate and sodium acetate were of analytical reagent grade (Merck, Germany). Diethylenetriaminepentaacetic acid (DTPA) was supplied by Acros Chemicals (Morris Plains, NJ, USA). Stock solutions of chromium, thallium, cadmium, lead, copper and antimony were NIST-USA SpecSol certified standard solutions at $1000 \mathrm{mg} \mathrm{g}^{-1}$. Working solutions were obtained by the appropriate mixing and dilution of individual stock solutions. The following concentrations were used: chromium, cadmium and antimony $1.0 \mathrm{mg} \mathrm{L}^{-1}$; thallium $2.5 \mathrm{mg} \mathrm{L}^{-1}$; lead $20.0 \mathrm{mg} \mathrm{L}^{-1}$ and copper $100.0 \mathrm{mg} \mathrm{L}^{-1}$. The stock supporting electrolyte solution was DTPA $\left(0.1 \mathrm{~mol} \mathrm{~L}^{-1}\right), \mathrm{NaNO}_{3}\left(5.0 \mathrm{~mol} \mathrm{~L}^{-1}\right)$ and $\mathrm{CH}_{3} \mathrm{COONa}$ $\left(0.4 \mathrm{~mol} \mathrm{~L}^{-1}\right)$. It was prepared by proper dissolution of the reagents in demineralized water.

\section{Real samples}

Four commercial DCs (identified herein as A, B, C and D) produced by distinct pharmaceutical industries and routinely employed by hemodialysis centers in Southern Brazil, were kindly supplied by the university hospital (HUSM). They had the following nominal compositions, as expressed in mol L-1: $3.6151 \mathrm{NaCl}, 0.0526 \mathrm{KCl}$, $0.0613 \mathrm{CaCl}_{2}, 0.0193 \mathrm{MgCl}_{2}$ and 0.1500 acetic acid. Each sample was received as furnished by the producer in sealed plastic bags having $3.4 \mathrm{~L}$ capacities.

\section{Analytical procedures}

Before starting the sequential determinations, a $10 \mathrm{~mL}$ aliquot of the sample was transferred from the original plastic bag to the voltammetric cell and thermostated at $20 \pm 0.5^{\circ} \mathrm{C}$. Subsequently, the stock supporting electrolyte solution $(1.0 \mathrm{~mL})$ was mixed with the sample. The initial $\mathrm{pH}$ value (6.2) was adjusted with a few drops of $25 \%(\mathrm{~m} / \mathrm{v})$ 
$\mathrm{NH}_{4} \mathrm{OH}$ solution. Deaeration interval of $300 \mathrm{~s}$ was used as prior starting the sequential method. Extra deaeration steps of $5 \mathrm{~s}$ were used during the standard addition method after each cell opening. The $\mathrm{pH}$ values necessary to run the sequential method were adjusted with $30 \%(\mathrm{~m} / \mathrm{v}) \mathrm{HCl}$ solution prepared with distilled $\mathrm{HCl}$. The standard addition method was applied by adding $10 \mu \mathrm{L}$ aliquots of the proper work solution to the voltammetric cell. A complete measurement for each step of the sequential method was obtained by running the sample voltammogram, followed by three voltammograms of successive $10 \mu \mathrm{L}$ additions of the proper working solution. After carrying out $\mathrm{pH}$ adjustments and working solution additions, the adequate volume correction factor was automatically included in the calculations by the software processor. Figure 1A through D schematically shows the potential program and $\mathrm{pH}$ gradient, along with the sequential methods, for assays of chromium, thallium, cadmium, lead, copper and antimony in DCs, respectively. A blank voltammogram was obtained by running the sequential method with $10 \mathrm{~mL}$ of demineralized water (Milli-Q system), instead of DCs, in the voltammetric cell.

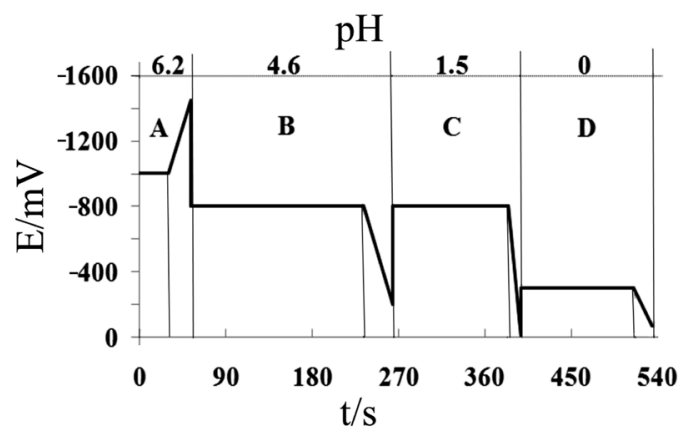

Figure 1. Potential program and $\mathrm{pH}$ gradient for the sequential voltammetric method. A) chromium, B) thallium, C) cadmium, thalliumlead, copper, D) antimony. Scan rate: $20 \mathrm{mV} \mathrm{s}^{-1}$ (A, B); $60 \mathrm{mV} \mathrm{s}^{-1}$ (C); $40 \mathrm{mV} \mathrm{s}^{-1}$ (D). Pulse amplitude: $-50 \mathrm{mV}$ (A); $50 \mathrm{mV}$ (B, C); $25 \mathrm{mV}$ (D).

\section{Results and Discussion}

Sequential voltammetric determinations of chromium, thallium, cadmium, lead, copper and antimony were based on the effect of the supporting electrolyte $\mathrm{pH}$ gradient on both the adsorption/desorption process of DTPA on the mercury electrode and the DTPA complexing ability towards the analytes present in DCs. A preliminary study (not shown) was carried out to find the best conditions of electrolyte $\mathrm{pH}$, DTPA concentration, deposition potentials, pulse amplitude and scan rate for the individual determination of each analyte by stripping voltammetry in DCs. This way, peak shape, peak overlapping and sensitivity were the main targets considering the possibility of mutual interference and the necessary sensitivity to make the method useful for the routine.

\section{Chromium, DTPA, pH gradient and sequential method}

The first procedure for trace chromium determination by AdCSV (adsorptive cathodic stripping voltammetry), described by Golimowski et al. ${ }^{13}$ was based on the preconcentration of a $\mathrm{Cr}$ (III)-DTPA complex at the HMDE surface and subsequent complex reduction in the presence of nitrate, for signal amplification. This adsorptive method was applied herein to assay chromium in DCs. DTPA species are electrochemically inactive in the potential range from 100 to $-1600 \mathrm{mV} .{ }^{14}$

In oxygenated solutions, $\mathrm{Cr}(\mathrm{VI})$, the most toxic chromium form, ${ }^{15-18}$ is the predominant species. Thus, it was considered as the chromium form present as a contaminant in DCs. The electrodic process for chromium determination occurs via the reduction of $\mathrm{Cr}$ (VI) to $\mathrm{Cr}$ (III) at the HMDE-DTPA electrode. Chromium (VI) begins irreversible reduction to $\mathrm{Cr}(\mathrm{III})$ on the HMDE at about $-200 \mathrm{mV} .{ }^{19}$ Among the chromium species, DTPA builds the most stable complex $\left(\mathrm{pK}_{\mathrm{stb}} 15.3\right)$ with $\mathrm{Cr}(\mathrm{III}) \cdot{ }^{20}$ Considering the complexing agents used in AdCSV for chromium determination, ${ }^{21}$ DTPA presents good performance for the sequential method. This is because it starts to be desorbed from the HMDE surface at a potential around $-800 \mathrm{mV}$ by changing the $\mathrm{pH}$ of the supporting electrolyte. Indeed, by lowering the $\mathrm{pH}$ from 6.2 to 4.6 , the sensitivity of chromium determination strongly decreases as a consequence of the low solubility of chromium in its "free form" on the mercury electrode. ${ }^{22}$

By means of cyclic voltammetry, AC voltammetry and electrocapillary measurements, the adsorption of DTPA has been shown to be reversible ${ }^{14}$ and $\mathrm{pH}$ dependent, as observed herein. Chromium (III) builds complexes with DTPA adsorbed to the electrode surface. Therefore, its complexing ability and adsorption on HMDE can be partially controlled by the $\mathrm{pH}$, considering the range of DTPA dissociation equilibria. Near pH 6, the adsorption of DTPA on the HMDE reaches its maximum value, probably due to the $\mathrm{H}_{2} \mathrm{Y}^{3-}$ species, which is the prevalent form ( $c$ a. 98\%). ${ }^{13,14,23}$ Figure $2 \mathrm{~A}$ through D show AC voltammograms of the charging currents (phase angle $=90^{\circ}$ ) as related to the adsorption/desorption process of DTPA, considering the $\mathrm{pH}$ gradient used over the entire potential range of the sequential method ( -1400 to $0 \mathrm{mV})$. At $\mathrm{pH} 6.2$, the decrease in charging current with respect to the voltammogram of the supporting electrolyte (Figure 2A) indicates the adsorption of DTPA molecules on the electrode surface. The hump in the DTPA curve over the potential range from 
-1250 to $-1450 \mathrm{mV}$ has been observed elsewhere ${ }^{14}$ and is attributed to the reorientation of DTPA molecules. This reorientation is due to the change in electrostatic interation between DTPA and the electrode. In the potential range of the chromium peak $\left(\mathrm{E}_{\text {peak }}=-1225 \mathrm{mV}\right)$, DTPA remained adsorbed onto the HMDE surface. Thus, the voltammetric signal corresponds to a $\mathrm{Cr}$ (III)-DTPA complex, as previously discussed. In the following potential windows for the sequential method (Figure 2B through D), the decreasing $\mathrm{pH}$ of the supporting electrolyte fits well with a gradual desorption of DTPA from the HMDE surface. At the lowest pH (Figure 2D), no DTPA adsorption was observed in the potential range from -300 to $0 \mathrm{mV}$.

\section{Thallium, cadmium, lead and copper}

Using voltammetric measurements in DCs, the thallium peak was anticipated of $c a .30 \mathrm{mV}$, in comparison with non-saline solutions, as a consequence of thallium chlorocomplex formation $\left(\log \mathrm{K}_{\mathrm{f}}=0.52\right) .{ }^{24}$ Similarly, anticipations of $c a .60,50$ and $150 \mathrm{mV}$ were observed by individual measurements in the absence of DTPA, for cadmium $\left(\log \mathrm{K}_{\mathrm{f}}=2.05\right),{ }^{24}$ lead $\left(\log \mathrm{K}_{\mathrm{f}}=1.62\right)^{24}$ and copper $\left(\log K_{\mathrm{f}}=2.36\right),{ }^{25}$ respectively. Indeed, in the high chloride media of DCs, with no influence of a stronger complexing agent (like DTPA), the peak potentials matched the formation constants of the chlorocomplexes. On the other hand, DTPA in alkaline or weakly acidic solutions built much more stable complexes with cadmium $\left(\log \mathrm{K}_{\mathrm{f}}=17.85\right)$, lead $\left(\log \mathrm{K}_{\mathrm{f}}=18.90\right)^{26}$ and copper $\left(\log \mathrm{K}_{\mathrm{f}}=21.45\right),{ }^{27}$ as compared with chloride ions. However, these DTPA complexes were promptly destabilized by acidification, owing to protonation reactions on coordination centers. As a consequence, good peak resolutions were obtained in chloride-DTPA solutions, owing to the combined action of gradual DTPA complex weakness by acidification together with peak potential shifts caused by chloride complex formation. Indeed, at $\mathrm{pH} 4.6$, thallium could be assayed $\left(\mathrm{E}_{\text {peak }}=-490 \mathrm{mV}\right)$ using anodic stripping voltammetry (Figure $3 \mathrm{~B}$ ) in the potential range from -800 to $-200 \mathrm{mV}$ (Figure 1B), while cadmium, lead and copper remained masked by the DTPA. By setting the $\mathrm{pH}$ to 1.5 (Figure 1C) and repeating the potential scan $(-800$ to $0 \mathrm{mV})$, three well-separated peaks were observed (Figure 3C). These included the cadmium peak $\left(E_{\text {peak }}=-640 \mathrm{mV}\right)$, a combined thallium-lead peak $\left(E_{\text {peak }}=-450 \mathrm{mV}\right)$ resulting from their well-known mutual interference, ${ }^{28-31}$ and the copper peak $\left(E_{\text {peak }}=-250 \mathrm{mV}\right)$. The concentration of lead was therefore calculated by difference, taking into account the thallium determination at $\mathrm{pH} 4.6$, where cadmium, lead and copper peaks were not observable.

In the present study, the method of standard additions was used throughout to quantify the analytes in DCs. Considering that lead was the only species determined by difference, the following comments related to the calibrations must be taken into account. Lead is expected to be present in DCs in higher concentrations than thallium, since the contamination sources by lead are the salts (mainly sodium chloride) used to make commercial formulations of DCs. In counterpart, the contamination source of thallium in DCs is potassium chloride (used in low concentrations) because thallium is a natural contaminant of potassium. ${ }^{2,4}$ In fact, there are few available data about contaminants measured directly in formulations of DCs. However, in all cases (including the present paper) lead was

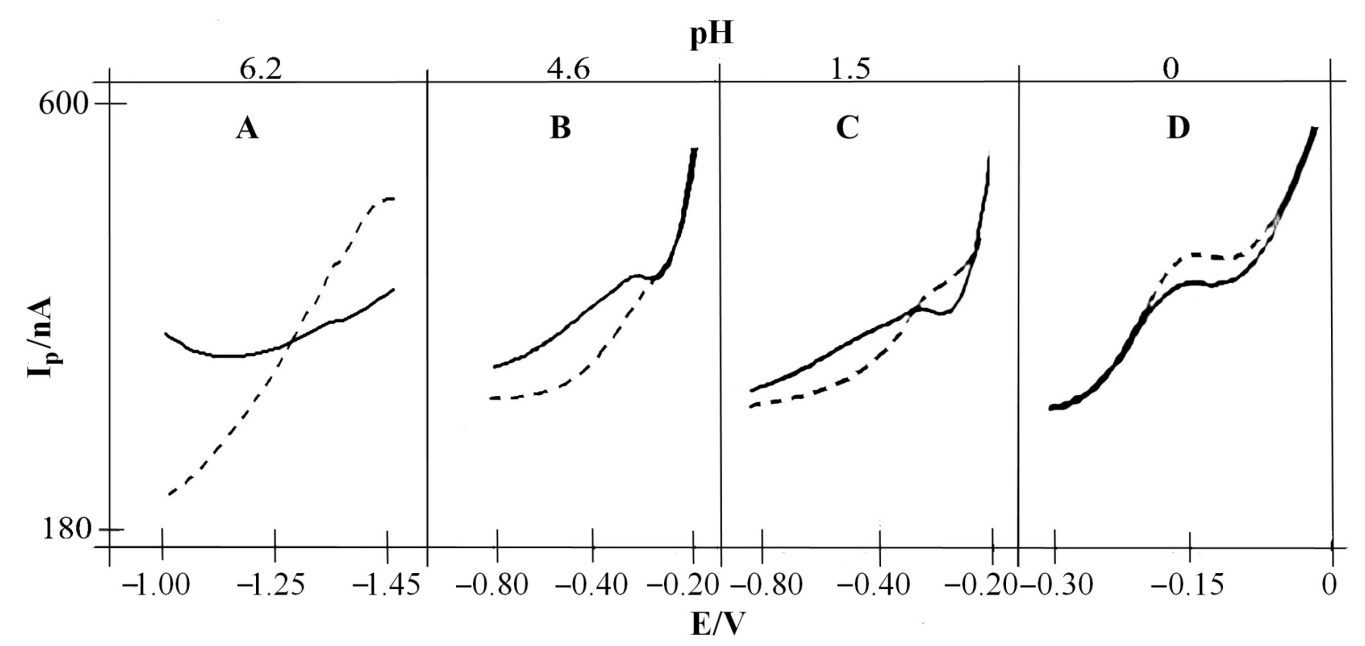

Figure 2. Alternating current voltammograms of the charging currents related to the adsorption/desorption process of DTPA at the mercury electrode surface. AC amplitude $20 \mathrm{mV}$, scan rate $20 \mathrm{mV} \mathrm{s}^{-1}$, frequency $60 \mathrm{~Hz}$ and phase angle $90^{\circ}$. Solid line: supporting electrolyte without DTPA. Dashed line: supporting electrolyte with DTPA. 
found always in much higher concentrations than thallium. ${ }^{4}$ This information was used here for the calibrations. Indeed, considering that reliable values for concentration ratios between lead and thallium in DCs range from $c a .10$ to 60, calibrations to assay lead by difference were adequately conducted according to the analytical procedure section. However, in case of much higher thallium concentrations comparatively to lead, the concentrations used for the standard addition method must be modified, taking into account that lead is assayed after additions of thallium to the voltammetric cell.

\section{Antimony, pH gradient, DTPA and chloride concentration}

Antimony, the last analyte of the sequential method, is only electroactive in very acidic solutions at potentials that are more positive than $-200 \mathrm{mV}$. Indeed, the voltammetric response of antimony related to $\mathrm{Sb}(\mathrm{III})$ and $\mathrm{Sb}(\mathrm{V})$ exhibits a well-known dependence on the acidity conditions and chloride content of the supporting electrolyte..$^{32-34}$ The stripping signal of $\mathrm{Sb}(\mathrm{V})$ became observable at high hydrochloric acid concentrations ( $\left.c a .4 \mathrm{~mol} \mathrm{~L}^{-1}\right)$, as well as by the proper setting of $\mathrm{HCl}-\mathrm{NaCl}$ mixtures containing less concentrated hydrochloric acid solutions. Under these conditions, a unique antimony voltammetric signal can be obtained irrespective of the oxidation states present in the samples. ${ }^{34}$ The dependence of peak currents on acidicchloride concentrations is the basis of antimony speciation analysis by voltammetry. ${ }^{34,35}$

In the present work, antimony was assayed in DCs by exploiting the high chloride content of these samples (ca. $3.8 \mathrm{~mol} \mathrm{~L}^{-1}$ ), combined with the final $\mathrm{pH}$ gradient step in the sequential method (Figure 1D). The acidic supporting electrolyte ( $\mathrm{pH} 0)$ impairs the masking ability of DTPA toward antimony. Therefore, antimony in its free form was assayed (Figure 3D) by scanning the potential over the range from -300 to $0 \mathrm{mV}\left(\mathrm{E}_{\text {peak }}=-140 \mathrm{mV}\right)$. Additionally, the peak overlapping between copper and antimony, as found in low salinity water samples, ${ }^{33,35}$ was not observed herein. This phenomenon was due to the anticipation of the copper signal caused by the high chloride concentration of the saline hemodialysis samples.

\section{Voltammograms and calibrations}

Following the analytical procedures and the potential program indicated in Figure 1, well-resolved voltammetric peaks were obtained for the entire sequential method. Figure 3A through D displays voltammograms, in which the first curves (a) are related to the analytes present as contaminants in DCs. The subsequent curves (b to d) are a result of the spiking experiments. The regression functions obtained for each analyte were $\mathrm{I}=(4.08 \pm 0.55) \mathrm{C}_{\mathrm{Cr}}+1.02 \pm 0.07$; $\mathrm{I}=(0.96 \pm 0.07) \mathrm{C}_{\mathrm{Tl}}+0.68 \pm 0.06 ; \mathrm{I}=(1.86 \pm 0.01) \mathrm{C}_{\mathrm{Cd}}+0.03$ $\pm 0.02 ; \mathrm{I}=(1.00 \pm 0.01) \mathrm{C}_{\mathrm{Pb}}+4.09 \pm 0.06 ; \mathrm{I}=(0.87 \pm 0.03)$ $\mathrm{C}_{\mathrm{Cu}}+0.35 \pm 0.08 ; \mathrm{I}=(2.38 \pm 0.36) \mathrm{C}_{\mathrm{Sb}}+1.76 \pm 0.03$. Peak current values (I) are expressed in $\mathrm{nA}$ and concentrations (C) in $\mu \mathrm{g} \mathrm{L}^{-1}$. In addition, Table 1 displays some important analytical characteristics of the sequential method. The limits of detection (LOD) and quantification (LOQ) were calculated according to the $3 \mathrm{~s} / \mathrm{m}$ and $10 \mathrm{~s} / \mathrm{m}$ criteria, ${ }^{36}$ respectively, where $s$ is the standard deviation $(n=8)$ of the intercept and $\mathrm{m}$ is the slope of each regression function.

The recommended maximum levels of chemical contaminants in dialysate (ANSI/AAMI RD 52 and 62) are the same as those for the water used to prepare it. This means that the DCs must not introduce in the dialysate a contamination level higher than the established limits for the water. In the regular practice, only the water is assayed against contaminants. The DCs are diluted by a factor of $c a .32$ with water to compose the dialysate just before each hemodialysis session ( $c a .3 .8 \mathrm{~L}$ of DCs are diluted to a final volume of $120 \mathrm{~L}$ ).

For measurements by stripping voltammetry the effect of deposition time on the sensitivity is well known, so that by using the conditions displayed in Table 1 , concentrations

Table 1. Parameters for the sequential voltammetric quantification of chromium, thallium, cadmium, lead, copper and antimony in dialysate concentrates

\begin{tabular}{|c|c|c|c|c|c|c|}
\hline Specie & $\begin{array}{c}\text { Linear range / } \\
\mu \mathrm{g} \mathrm{L}^{-1}\end{array}$ & $\begin{array}{l}{ }^{1} \mathrm{HW} \text { Limit } \\
\text { conc. / } \mu \mathrm{g} \mathrm{L}{ }^{-1}\end{array}$ & $\begin{array}{l}{ }^{2} \text { DC Equivalent } \\
\text { conc. / } \mu \mathrm{g} \mathrm{L}^{-1}\end{array}$ & $\begin{array}{c}\text { Deposition } \\
\text { time / s }\end{array}$ & $\begin{array}{l}\text { LOD / } \\
\mu \mathrm{g} \mathrm{L}^{-1}\end{array}$ & $\begin{array}{l}\text { LOQ / } \\
\mu \mathrm{g} \mathrm{L}^{-1}\end{array}$ \\
\hline $\mathrm{Cr}$ & $0.20-50$ & 14 & 448 & 30 & 0.05 & 0.16 \\
\hline $\mathrm{Tl}$ & $0.80-300$ & 2 & 64 & 180 & 0.19 & 0.63 \\
\hline $\mathrm{Cd}$ & $0.14-600$ & 1 & 32 & 120 & 0.03 & 0.11 \\
\hline $\mathrm{Pb}$ & $0.80-600$ & 5 & 160 & 120 & 0.19 & 0.64 \\
\hline $\mathrm{Cu}$ & $1.20-600$ & 100 & 3200 & 120 & 0.27 & 0.93 \\
\hline $\mathrm{Sb}$ & $0.16-200$ & 6 & 192 & 120 & 0.04 & 0.13 \\
\hline
\end{tabular}

${ }^{1}$ AAMI limits for HW; ${ }^{2}$ see text. 

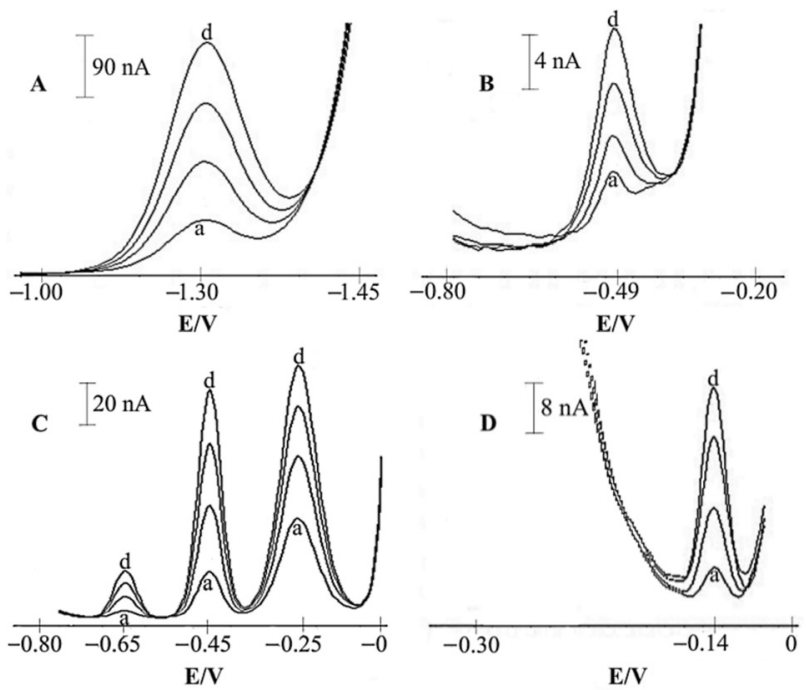

Figure 3. Typical sequential voltammograms in saline hemodialysis concentrates (curves a) for A) chromium; B) thallium; C) cadmium, thallium-lead, copper; D) antimony. Curves b to d: spiking experiments. All other conditions are as in Figure 1.

of contaminants in DCs even lower than the permitted values for HW can be reached. For comparison, the third and fourth columns in Table 1 display, respectively, the concentration limits of the contaminants for HW (ANSI/AAMI RD 52 and 62) and the calculated equivalent concentration for DCs considering the correction factor of 32. The displayed LOQ values are related to a condition of maximum sensitivity. For all analytes, the LOQ was much lower than the equivalent concentration values, which is mandatory to assure the utility of this method for the quality control of DCs. Therefore, in the routine significant reductions in the analysis duration can be achieved by changing the deposition times. Figure 4 shows the variations on LOQ values as function of deposition times. To assay the equivalent concentrations in DCs, deposition times indicated by arrows in Figure 4 were enough so that a reduction from 690 to $75 \mathrm{~s}$ was feasible. This means a decrease from 50 (condition of maximum sensitivty) to $c a .12 \mathrm{~min}$ on the total analysis duration. In both cases, the analysis duration is aceptable considering the direct determination of six analytes in DCs without sample preparation or cleanup steps.

\section{Analytical application}

The potential sources of the contamination of DCs by chromium, thallium, cadmium, lead, copper and antimony are the salts of sodium, potassium, calcium and magnesium used to prepare the DCs. ${ }^{2}$ Sequential method was used to assay the analytes in four commercial samples. The aim of this work was not to perform a systematic determination of chromium, thallium, cadmium, lead, copper and antimony in a great number of real samples, but instead to provide a methodology for such determinations. Table 2 shows the detected concentrations as well as the recoveries from spiked commercial samples. In most cases, the samples presented some contamination by the assayed metallic ions. However, the concentrations were under the equivalent

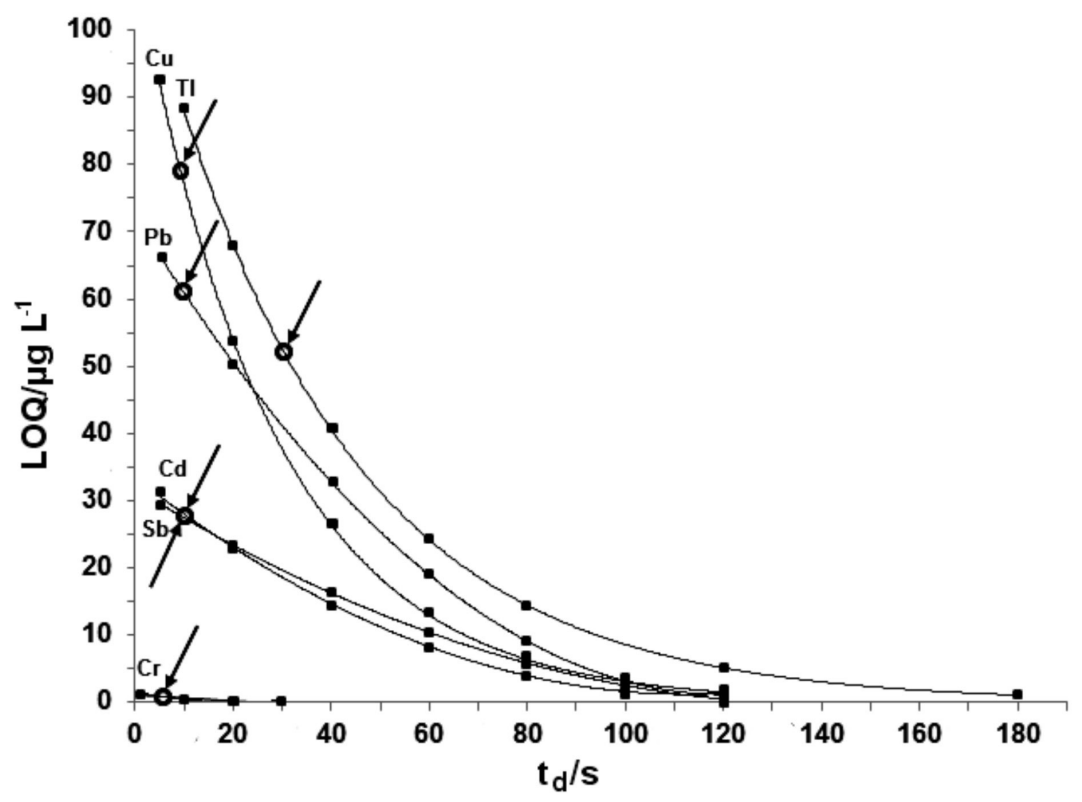

Figure 4. Limits of quantification for chromium, thallium, cadmium, lead, copper and antimony as function of deposition time for the sequential voltammetric method. All other conditions are as in Figure 1. (Arrows see text). 
concentrations displayed in Table 1. For the present case, this finding indicates that the investigated samples (A, B, $\mathrm{C}$ and D) would not introduce contamination levels of chromium, thallium, cadmium, lead, copper and antimony higher than the established limits for HW into the final hemodialysis fluid. The recoveries were close to $100 \%$ for all analytes.

\section{Interferences}

The study designed to assess the selectivity of the proposed method was focused on the signal overlapping caused by the mutual interference among the analytes, as well as on the specific influences caused by mercury, zinc, aluminum, arsenic, selenium and silver on the analyte signals. This group represents the complementary portion of metals, regulated by the ANSI/AAMI RD 52 and 62 standards for HW, which show electrochemical activity. Mutual interference among the analytes was not observed herein, as can be seen in Figure 3. For the high chloride concentration of DCs, thallium, lead, cadmium and copper showed significant peak potential shifts, as previously discussed; however, this phenomenon occurred without causing peak overlaps. Similarly, no changes on the peak shapes were observed for the analytes when the aforementioned group of electrochemically active metals was present in the voltammetric cell in large excess (5 times) relative to the highest concentration of the linear calibration range (Table 1) for each analyte. Additionally, no significant effect on peak intensity as well as on the selectivity was also observed when the investigated group of potential interferents was simultaneously present in the voltammetric cell.

\section{Method validation}

For the determinations of chromium, thallium, cadmium, lead, copper and antimony in DCs, neither reference standard methods nor reference materials are presently available. Therefore, to validate the proposed method, we considered both the recovery experiments displayed in Table 3 and the regression analysis between the analyte concentrations, obtained by measuring spiked samples, with the proposed method and the ETAAS method adapted from Bohrer et al., ${ }^{2}$ which was used as a comparative method. The samples were spiked with the analytes in three levels at concentrations ranging from 500 to $15,000 \mu \mathrm{g} \mathrm{L}^{-1}$. These samples were then diluted 500 times and directly analyzed using both methods. This strategy was necessary to overcome the interference caused by the high saline concentration on the ETAAS measurements. Before measurements by the voltammetric method, sodium and
Table 2. Determination and recovery for chromium, thallium, cadmium, lead, copper and antimony in dialysate concentrates by sequential voltammetry

\begin{tabular}{|c|c|c|c|c|}
\hline Species & aSample & $\begin{array}{l}\text { Added / } \\
\mu \mathrm{g} \mathrm{L}^{-1}\end{array}$ & $\begin{array}{c}\text { betected / } \\
\mu \mathrm{g} \mathrm{L}^{-1}\end{array}$ & $\begin{array}{c}\text { Recovery } \\
(\%)\end{array}$ \\
\hline \multirow[t]{6}{*}{ Chromium } & A & - & $0.34 \pm 4$ & - \\
\hline & B & - & $0.25 \pm 3$ & - \\
\hline & $\mathrm{C}$ & - & $0.49 \pm 3$ & - \\
\hline & $\mathrm{D}$ & - & $0.27 \pm 6$ & - \\
\hline & A & 2.00 & $2.35 \pm 1.1$ & 100.5 \\
\hline & $\mathrm{B}$ & 1.00 & $1.17 \pm 2$ & 92.0 \\
\hline \multirow[t]{6}{*}{ Thallium } & A & - & $0.85 \pm 1.5$ & - \\
\hline & B & - & $<\mathrm{LOD}$ & - \\
\hline & $\mathrm{C}$ & - & $<\mathrm{LOD}$ & - \\
\hline & $\mathrm{D}$ & - & $<$ LOD & - \\
\hline & A & 5.00 & $6.24 \pm 0.8$ & 107.8 \\
\hline & $\mathrm{B}$ & 2.00 & $2.02 \pm 1.4$ & 101.0 \\
\hline \multirow[t]{6}{*}{ Cadmium } & A & - & $0.18 \pm 5$ & - \\
\hline & B & - & $<\mathrm{LOD}$ & - \\
\hline & $\mathrm{C}$ & - & $<$ LOD & - \\
\hline & $\mathrm{D}$ & - & $0.14 \pm 8$ & - \\
\hline & A & 1.00 & $1.14 \pm 2.5$ & 96.0 \\
\hline & B & 5.00 & $4.73 \pm 0.9$ & 94.6 \\
\hline \multirow[t]{6}{*}{ Lead } & A & - & $10.77 \pm 1.2$ & - \\
\hline & B & - & $7.50 \pm 1.2$ & - \\
\hline & $\mathrm{C}$ & - & $4.43 \pm 1.4$ & - \\
\hline & $\mathrm{D}$ & - & $4.18 \pm 1.6$ & - \\
\hline & A & 10.00 & $21.68 \pm 0.9$ & 109.1 \\
\hline & B & 20.00 & $26.47 \pm 0.6$ & 94.9 \\
\hline \multirow[t]{6}{*}{ Copper } & A & - & $22.53 \pm 1.0$ & - \\
\hline & B & - & $47.41 \pm 1.1$ & - \\
\hline & $\mathrm{C}$ & - & $140.00 \pm 0.6$ & - \\
\hline & $\mathrm{D}$ & - & $20.36 \pm 0.6$ & - \\
\hline & A & 100.00 & $140.03 \pm 0.4$ & 117.5 \\
\hline & B & 40.00 & $85.90 \pm 0.4$ & 96.2 \\
\hline \multirow[t]{6}{*}{ Antimony } & A & - & $0.38 \pm 4$ & - \\
\hline & B & - & $<\mathrm{LOD}$ & - \\
\hline & $\mathrm{C}$ & - & $<\mathrm{LOD}$ & - \\
\hline & $\mathrm{D}$ & - & $0.16 \pm 8$ & - \\
\hline & A & 1.00 & $1.37 \pm 3.5$ & 99.0 \\
\hline & B & 2.00 & $2.00 \pm 1.4$ & 100.0 \\
\hline
\end{tabular}

${ }^{\mathrm{a} C o m m e r c i a l ~ D C s ; ~}{ }^{\mathrm{b} S D}$ : $\mathrm{n}=3$.

potassium chlorides were added to the samples to restore the original level present in DCs. The regression analysis showed that the methods produced similar results. Indeed, the regression characteristics for each analyte obtained by least-squares fitting between the methods presented slopes 
and intercepts that did not differ significantly from 1 and 0 , respectively.

\section{Conclusion}

The method described herein enables the voltammetric sequential determination of chromium, thallium, cadmium, lead, copper and antimony directly in DCs, without requiring a sample dilution to overcome matrix interferences. The method sensitivity permits the performance of analyte assays at concentrations lower than the values regulated by the ANSI/AAMI RD 52 and 62 standards for HW. Therefore, the proposed methodology could be an easy option for the pharmaceutical industry or for regulatory agencies to introduce in the quality control of DCs. It is important to point out that in the regular practice of hemodialysis, the dialysate (DCs dissolved in HW) is not monitored for chemical contamination. Thus, unwanted species present in DCs may be delivered to the patients, despite the use of high quality HW.

\section{Acknowledgements}

We are grateful to the Brazilian foundations $\mathrm{CNPq}$ and CAPES (Probral No. 240/06) for scholarship support.

\section{References}

1. Vorbeck-Meister, I.; Sommer, R.; Vorbeck, F.; Hörl, W. H.; Nephrol. Dial. Transplant. 1999, 14, 666.

2. Bohrer, D.; do Nascimento, P. C.; Guterres, M.; Trevisan, M.; Seibert, E.; Analyst 1999, 124, 1345.

3. do Nascimento, P. C.; Bohrer, D.; de Carvalho, L. M.; Caon, C. E.; Pilau, E.; Vendrame, Z. B.; Stefanello, R.; Talanta 2005, $65,954$.

4. Carvalho, L. M.; do Nascimento, P. C.; Koschinsky, A.; Bau, M.; Stefanello, R. F.; Spengler, C.; Bohrer, D.; Jost, C.; Electroanalysis 2007, 19, 1719.

5. D'Haese, C.; De Broe, M. E.; Nephrol. Dial. Transplant 1996, 11,92 .

6. Savory, J.; Wills, M. R.; Clin. Chem. 1992, 38, 1565.

7. Mallinckrodt, M. G.; Spurenelemente in der Nephrologie, Dustri Verlag: München-Deisenhofen, 1983.

8. Alfrey, M. D.; Allen, C.; N. Engl. J. Med. 1984, 310, 1113.

9. Stoeppler, M. In Metals and their Compounds in the Environment; Merian, E., ed.; VCH: Weinheim, 1999.
10. Association for the Advancement of Medical Instrumentation, Hemodialysis Systems, ANSI/AAMI RD5-1992, Arlington, AAMI 1993a American National Standard. http://marketplace. aami.org/.

11. Subramanian, K. S.; Prog. Anal. Spectrosc. 1986, 9, 237.

12. Henze, G.; Polarographie und Voltammetrie - Grundlagen und Analytische Praxis; Springer-Verlag: Berlin Heidelberg, 2001.

13. Golimowski, J.; Valenta, P.; Nürnberg, H.; Fresenius Z. Anal. Chem. 1985, 322, 315.

14. Sander, S.; Navrátil, T.; Novotny, L.; Electroanalysis 2003, 19 , 1513.

15. Sirinawin, W.; Westerlund, S.; Anal. Chim. Acta 1997, 356, 35.

16. Cranston, R.; Murray, J.; Anal. Chim. Acta 1978, 99, 275.

17. Boussemart, M.; van den Berg, C. M. G.; Ghaddaf, M.; Anal. Chim. Acta 1992, 262, 103.

18. van den Berg, C. M. G.; Boussemart, M.; Yokoi, K.; Prartono, T.; Campos, M. L. A. M.; Mar. Chem. 1994, 45, 267.

19. Korolczuk, M.; Grabarczyk, M.; Anal. Chim. Acta 1999, 387, 97.

20. Li, Y.; Xue, H.; Anal. Chim. Acta 2001, 448, 121.

21. Bobrowsky, A.; Królicka, A.; Zarebski, J.; Electroanalysis 2009, $21,1449$.

22. Scholz, F.; Lange, B.; Draheim, M.; Pelzer, J.; Fresenius J. Anal. Chem. 1990, 338, 627.

23. Sander, S.; Navrátil, T.; Bašová, P.; Novotny, L.; Electroanalysis 2002, 14, 1133.

24. Lurie, J.; Handbook of Analytical Chemistry, Mir Publishers: Moscow, 1978.

25. Bjerrum, J.; Skibsted, L. H.; Inorg. Chem. 1986, 25, 2479.

26. Crouch, A. M.; Khotseng, L. E.; Polhuis, M.; Williams, D. R.; Anal. Chim. Acta 2001, 448, 231.

27. Baumann, E. W.; J. Inorg. Nucl. Chem. 1974, 36, 1827.

28. Neeb, R.; Fresenius J. Anal. Chem. 1959, 171, 321.

29. Dhaneshwar, R. G.; Zarapkar, L. R.; Analyst 1980, 105, 386.

30. Gemmer-Colos, V.; Kiehnast, I.; Trenner, J.; Neeb, R.; Fresenius J. Anal. Chem. 1981, 306, 144.

31. You, N.; Neeb, R.; Fresenius J. Anal. Chem. 1983, 314, 394.

32. Ghoneim, M. M.; Hassanein, A. M.; Hammam, E.; Fresenius J. Anal. Chem. 2000, 367, 378.

33. Zong, P.; Nagaosa, Y.; Microchim. Acta 2009, 166, 139.

34. Quentel, F.; Filella, M.; Anal. Chim. Acta 2002, 452, 237.

35. Bond, A. M.; Kratsis, S.; Newman, O. M. G.; Electroanalysis 1997, 9, 681.

36. Miller, J. C.; Miller, J. N.; Statistics for Analytical Chemistry, $4^{\text {th }}$ ed.; Ellis-Howood: New York, 1994.

Submitted: August 23, 2010 Published online: January 27, 2011 